\title{
Prognostic differences among patients with idiopathic interstitial pneumonias with acute exacerbation of varying pathogenesis: a retrospective study
}

Motoyasu Kato ${ }^{*}$ (D) Tomoko Yamada, Shunichi Kataoka, Yuta Arai, Keita Miura, Yusuke Ochi, Hiroaki Ihara, Ryo Koyama, Shinichi Sasaki and Kazuhisa Takahashi

\begin{abstract}
Background: Acute exacerbation of chronic fibrosing idiopathic interstitial pneumonias (AE-IIPS) is associated with a high mortality rate. In 2016, an international working group proposed a revised diagnostic criteria for AE-IIPS, suggesting that it be classified as idiopathic or triggered. Many factors are known to trigger AE-IIPs, including surgery, infection, and drugs. However, it is unknown which AE-IIPs triggers have a worse prognosis. We aimed to investigate the prognosis of patients with various clinical types of AE-IIPS, particularly infection-triggered, noninfection triggered, and idiopathic AE-IIPS.

Methods: We retrospectively collected data from 128 chronic fibrosing IIPS (CF-IIPS) patients who were hospitalized by respiratory failure between April 2009 and March 2019 at Juntendo University Hospital. Among these patients, we evaluated 79 patients who developed AE-IIPs and 21 who developed pneumonia superimposed on CF-IIPS. Patients with AE-IIPs were classified into three types: idiopathic, infection-triggered, and non-infection-triggered AEIIPs. We analyzed differences in patient characteristics, examination findings; level of serum markers, results of pulmonary function, and radiological findings, prior treatment for baseline CF-IIPs, and prognosis. We then evaluated the risk factor for early death (death within 30 days from the onset of AE-IIPS) associated with AE-IIPS.

Results: Among the patients who developed AE-IIPS, 34 were characterized as having idiopathic, 25 were characterized as having infection-triggered, and 20 were categorized as having non-infection-triggered AE-IIPs. Survival time for pneumonia superimposed on IIPs was significantly longer than that for any AE-IIPs. Survival time for bacterial pneumonia superimposed on CF-IIPs was significantly longer than that for AE-IIPs (for each idiopathic and all triggered IIPs). Thereafter, survival time for infection-triggered was significantly longer than for idiopathic or non-infection-triggered AE-IIPS. The mortality rate was significantly lower in infection-triggered AE-IIPs than in other types of AE-IIPS. Furthermore, the incidence of infection-triggered AE-IIPs in winter was significantly higher than that in other seasons. Moreover, the clinical AE-IIPs types and radiological findings at AE-IIP onset were significant risk factors for AE-IIPs-induced early death.
\end{abstract}

Conclusions: Our findings suggest that patients with infection-triggered AE-IIPS can expect a better prognosis than can patients with other clinical types of AE-IIPS.

Keywords: Idiopathic interstitial pneumonias, Idiopathic pulmonary fibrosis, Acute exacerbation, Trigger, Infection

\footnotetext{
* Correspondence: mtkatou@juntendo.ac.jp

Department of Respiratory Medicine, Juntendo University Graduate School of

Medicine, 3-1-3, Hongo, Bunkyo-ku, Tokyo 113-8431, Japan
}

(c) The Author(s). 2019 Open Access This article is distributed under the terms of the Creative Commons Attribution 4.0 International License (http://creativecommons.org/licenses/by/4.0/), which permits unrestricted use, distribution, and reproduction in any medium, provided you give appropriate credit to the original author(s) and the source, provide a link to the Creative Commons license, and indicate if changes were made. The Creative Commons Public Domain Dedication waiver (http://creativecommons.org/publicdomain/zero/1.0/) applies to the data made available in this article, unless otherwise stated. 


\section{Background}

Acute exacerbation of idiopathic pulmonary fibrosis (AE-IPF) was first reported in 1993 [1]. The incidence of AE is reported to be approximately $10-20 \%$ in IPF [2]. Furthermore, AE-IPF is known to be associated with a high mortality rate of approximately $30-50 \%$ [3].

Diagnostic criteria for AE-IPF were first published in 2007 [4]. These included a previous diagnosis of interstitial pneumonia, including IPF, unexplained worsening of dyspnea in the past month, high resolution computed tomography (HRCT) evidence of new bilateral groundglass opacities (GGO) or consolidation, and exclusion of alternative reasons for exacerbation, including pulmonary infection, and heart or renal failure. Recently, there have been descriptions of $\mathrm{AE}$ associated with other progressive fibrosing interstitial pneumonias, including nonspecific interstitial pneumonia, chronic hypersensitivity pneumonia, and connective tissue disease-related interstitial pneumonia [5-9]. Patients with AE associated with these conditions have a worse prognosis, and it is believed to reflect disease progression in both progressive fibrosing interstitial pneumonias.

In 2016, Collard et al. published an International Working Group Report on AE-IPF [2]. This report suggested that clinical AE-IPF types should be categorized as "idiopathic" or "triggered." Known triggers of AE include infection, surgery, medication, any biopsy, and bronchoscopy [10-17]. Despite this categorization, it is not known which of the two subtypes of AE have a worse prognosis. Moreover, we focus on differences between AE triggers, especially the difference between infective and non-infective triggers (e.g., drugs, surgery, or bronchoscopy). It is also not known whether infective triggers are associated with worsening prognosis. Then, we focus on AE associated with chronic fibrosing idiopathic interstitial pneumonias (AE-IIPs), including IPF, and evaluate differences in patient characteristics and examination results. Therefore, we purposed to evaluate prognosis for different characteristics and among idiopathic, infection-triggered, and non-infection-triggered AE-IIPs.

\section{Methods}

\section{Patient selection and evaluations}

We collected data for chronic fibrosing IIPs (CF-IIPs) patients who were hospitalized by respiratory failure between April 2009 and March 2019 at Juntendo University Hospital. We defined patients with CF-IIPs as having IPF, idiopathic non-specific interstitial pneumonia (NSIP), and idiopathic unclassifiable interstitial pneumonia (UCIP) based on the international IIPs classification by American thoracic society (ATS) and European respiratory society and a previous report [18, 19]. Initially, we excluded patients who presented with complications of congestive heart failure (CHF) or pneumothorax/mediastinum emphysema. From the remaining pool, we further excluded those with advanced lung cancer because we considered that the prognosis of patients with advanced lung cancer to be shorter than that of patients with CF-IIPs. Thereafter, we categorized the remainder of the patients into those with pneumonia superimposed on CF-IIPs and patients with AE-IIPs. Subsequently, we evaluated the difference in patient characteristics and prognosis between patients with pneumonia superimposed on CF-IIPs and those with AE-IIPs. Moreover, patients who developed AEIIPs were included and classified into three clinical AEIIPs types such as: idiopathic, infection-triggered, and non-infection-triggered AE-IIPs. We evaluated differences among the three groups in patient characteristics, baseline CF-IIPs pattern, baseline pulmonary function performed within 6 months from the development of AE-IIPs, pre-exiting CF-IIPs pattern, treatment prior to AE-IIPs, $\mathrm{PaO}_{2} / \mathrm{FiO}_{2}$ ratio, laboratory data (including white serum blood cell count, lactate dehydrogenase (LDH), C-related protein [CRP], Krebs von den Lungen6 [KL-6], and surfactant protein-D [SP-D]), HRCT patterns at time of diagnosis of AE-IIPs, survival time, mortality, and seasonal variations. We evaluated HRCT findings at the time of diagnosis of AE-IIPs according to Akira's previous publication, defining them as diffuse, multifocal, and peripheral patterns [20]. Three physicians (M.K., R.K., and S.S.) blindly reviewed the HRCT scans prior to the development of AE-IIPs and at the onset of AE-IIPs. Subsequently, we also evaluated risk factors for early death induced by AE-IIPs. Further, we defined early death as death within 30 days of onset.

\section{Defining AE-IIPs and triggers}

AE-IIPs was diagnosed based on the ATS criteria (2016) [2] as follows: previous or concurrent diagnosis of any CF-IIPs, acute worsening or development of dyspnea typically of 1 month duration, and HRCT with new bilateral GGO and/or consolidation, superimposed on a background pattern associated with CF-IIPs and deterioration that is not fully explained by cardiac failure or fluid overload. We then divided patients who developed AE-IIPs into three groups based on the attending physician's decision: idiopathic, infection-triggered, and noninfection-triggered. Moreover, we confirmed the findings associated with triggers as follows.

Post-operative AE-IIPs were defined as having been induced by any operation performed in an operating room that developed within a month after surgery. Druginduced AE-IIPs were defined as having occurred after administration of the suspected drug and presence of previous reports of a drug-induced lung injury that developed within 3 months after drug initiation. Post-lung 
biopsy AE-IIPs were defined as those induced by bronchoscopy or percutaneous lung biopsy that developed within a month after the examinations. Infectiontriggered AE-IIPs were defined as those induced by infection of the upper respiratory tract, contracted within 2 weeks prior to development of AE-IIPs, presenting with symptoms associated with upper respiratory tract inflammation, including high fever ( $>37.5$ degree, sore throat, worsening cough and worsening dyspnea, and/or virus positive, particularly influenza virus, or evidence of other infection. Bacterial pneumonia superimposed on CF-IIPs was defined as consolidation of the baseline interstitial shadow on HRCT images with evidence of bacterial infection, including positive serum procalcitonin, and/or positive smear or cultures of sputum and/or blood. We then distinguished between infectiontriggered AE-IIPs and bacterial pneumonia superimposed on CF-IIPs based on attending physician's decision. Patients with bacterial pneumonia superimposed on CF-IIPs were diagnosed by confirming elevated CRP and/or procalcitonin levels without elevated LDH, KL-6, and SP-D levels, and a consolidation area larger than the GGO area on HRCT. These criteria hold true except in cases of pneumothorax, pulmonary embolism or CHF, renal failure, and cases for which the main etiology was bacterial pneumonia.

We also evaluated seasonal variations among the three clinical AE-IIPs types. Seasons were defined as follows: between March and May as spring, between June and August as summer, between September and November as autumn, and between December and February as winter.

\section{Statistical analysis}

We used the chi-square test, Fisher's exact test, or Wilcoxon two-sample test to evaluate the frequency of any types of acute exacerbation and compare patient characteristics among these groups. Parametric and nonparametric data were compared with Student's t-test and the Mann-Whitney U test, respectively. Differences in median survival time (MST) were analyzed with the logrank test. Cox proportional hazard analysis was used to calculate hazard ratios (HRs), and univariate and multivariate logistic regression analyses were used to determine the risk factors for the AE-IIPs. A $p$-value of $<0.05$ was considered statistically significant. All statistical analyses were performed with SPSS version 19.0 for Windows (Chicago, IL, USA).

\section{Results}

\section{Patient characteristics}

We identified 128 CF-IIPs patients who were hospitalized by respiratory failure. From these patients, we excluded patients with pneumothorax or mediastinal emphysema $(n=16)$, CHF $(n=2)$, or terminal stage of any cancer $(n=10)$. Among them, 21 patients developed bacterial pneumonia superimposed on CF-IIPs; thus, we included 79 patients with CF-IIPs and with clinically diagnosed AE-IIPs (Fig. 1). Furthermore, patients were classified into three clinical types of AE-IIPs: idiopathic $(n=34)$, infection-triggered $(n=25)$, and non-infectiontriggered $(n=20)$. Among the patients with infectiontriggered AE-IIPs, 5 patients had a possible influenza infection, and all patients had symptoms related to upper respiratory tract infection, high fever or sore throat. Among patients who developed non-infectiontriggered AE-IIPs, 12 had a history of new drug initiation, 5 had recently undergone operations, and 3 had received recent bronchoscopy or percutaneous lung biopsy. Patients with drug-induced AE-IIPs had received anti-cancer drugs $(n=6)$, including paclitaxel $(n=2)$, gemcitabine $(n=1)$, doxolbicine $(n=1)$, and axitinib $(n=1)$, antihypertensives (amlodipine) ( $n=1)$, antibiotics (levofloxacin) $(n=1)$, anti-inflammatory drugs $(n=2)$, including loxoprofen $(n=1)$ and ibuprofen $(n=1)$, and herbal medications $(n=2)$, including Bofu-tsusho-san $(n=1)$ and Sho-saiko-to $(n=1)$.

Table 1 presents the patient characteristics. All patients were Japanese, with a median age of 74 years (range: 62-85 years). There were 66 men (83.52\%). Sixty-one patients (77.22\%) had a history of smoking, and 13 patients (16.46\%) smoked until the development of AE-IIPs. Fifty-nine patients were diagnosed with IPF and 20 had UCIP prior to the development of AE-IIPs. There were no significant differences in patients characteristics among the three clinical AE-IIPs types. Prior to the development of AE-IIPs, 47 patients had received no treatment for CF-IIPs, while there were 9,6,9,4, and 4 patients treated with corticosteroids, corticosteroid plus immunosuppressants, pirfenidone, nintedanib, and corticosteroid plus nintedanib, respectively. All patients first received $1 \mathrm{~g}$ of methylprednisolone and $1 \mathrm{mg} / \mathrm{kg}$ of corticosteroid after steroid pulse therapy. There were no significant differences in prior treatment for baseline CF-IIPs between the groups (Table 1).

In addition, comparison of patient backgrounds between patients with AE-IIPs and those with pneumonia superimposed on CF-IIPs showed no significant differences in parameters, including age, sex, smoking history, baseline CF-IIPs pattern, and prior treatment for CFIIPs (Table 2).

\section{AE-IIPs characteristics}

HRCT indicated a diffuse pattern in 34 patients, a multifocal pattern in 14 patients, and a peripheral pattern in 31 patients at the time of diagnosis of AE-IIPs. There were no significant differences in HRCT patterns associated with AE-IIPs among the three groups. For AE-IIPs- 


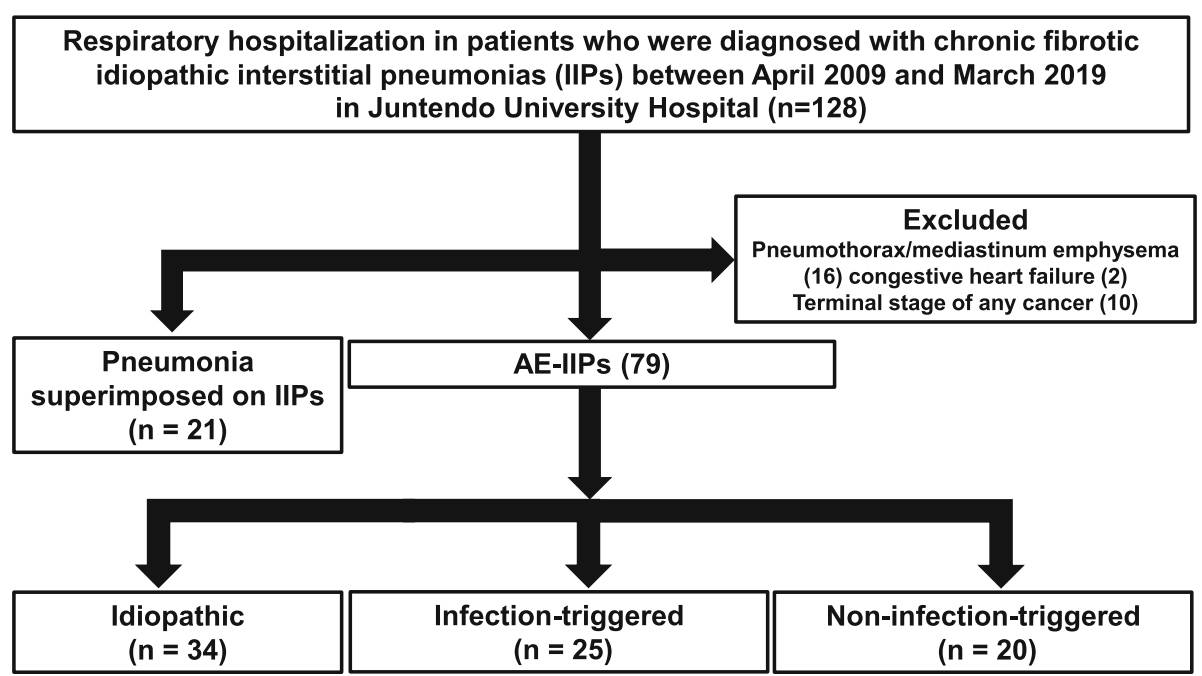

Fig. 1 Flowchart of patient recruitment

associated clinical symptoms, including high fever (> 37.5 degree), worsening cough, and worsening dyspnea, the number of patients with high fever tended to be higher in infection-triggered AE-IIPs than in other clinical AE-IIPs types $(p=0.094)$. For other symptoms related to AE-IIPs or CF-IIPs, including worsening cough and dyspnea, there were no significant differences in these symptoms among these groups. In contrast, there were no significant differences in other symptoms, including worsening cough and dyspnea.

Among the serum markers, although serum CRP in infection-triggered patients was significantly higher than other clinical AE-IIPs types, the serum procalcitonin levels was significantly higher in infection-triggered AE-IIPs than in patients with all total AE-IIPs. Then, the serum procalcitonin was significantly higher in infection-triggered AE-IIPs than in idiopathic AE-IIPs $(p=0.037)$. Moreover, serum LDH levels tended to be higher in non-infection triggered patients than those in other types of AE-IIPs. In contrast, there were no significant differences in other serum markers, including KL-6 and SP-D, as well as the $\mathrm{PaO}_{2} / \mathrm{FiO}_{2}$ ratio among the three groups. Among pulmonary function measures, although forced vital capacity (FVC) and vital capacity (VC) were significantly higher in noninfection-triggered AE-IIPs, there was no significant difference in diffusion capacity (DLco) among the three groups (Table 1).

In addition, symptoms, serum marker levels, and pulmonary function were compared between patients with pneumonia superimposed on CF-IIPs and those with AE-IIPs. The number of patients with high fever and sore throat in the bacterial pneumonia group were significantly higher than those in the AE-IIPs group $(p=0.027$ and $p=0.008$, respectively).Although there was no significant difference in the serum WBC counts, serum KL-6, SP-D, and D-dimer levels in patients with AE-IIPs were significantly higher than those with pneumonia superimposed on CF-IIPs. In contrast, serum CRP and procalcitonin level was significantly lower in patients with AE-IIPs than in those with pneumonia superimposed on CF-IIPs. In addition, the serum procalcitonin was significantly higher in bacterial pneumonia superimposed on CF-IIPs than in infection-triggered AE-IIPs $(p=0.001)$.

Moreover, the baseline pulmonary function parameter, DLco, was significantly lower in patients with pneumonia superimposed on CF-IIPs than in those with AE-IIPs, whereas there were no significant differences in FVC and $\mathrm{VC}$ between the two groups. An echocardiography was performed to evaluate left and/or right heart failure and pulmonary embolism in all patients diagnosed with AEIIPs, including the patients with elevated D-dimer levels. No patients were found to have left/right heart failure and embolism using an echocardiography (Table 2).

All patients with AE-IIPs were treated with intravenous high-dose corticosteroids and an antibiotic. Approximately $40 \%$ of these patients were also treated with immunosuppressants. We performed invasive ventilation with only a few patients but administered high-flow therapy to over $60 \%$ of the patients. However, there were no significant differences in treatment and use of ventilation among the different types of AE-IIPs (Table 3). When comparing the difference in treatment between patients who were diagnosed with AE-IIPs and those who were diagnosed with bacterial pneumonia superimposed on CF-IIPs, although all patients received antibiotics for both AE-IIPs and bacterial pneumonia superimposed on CF-IIPs, no patients received additional corticosteroids and/or immunosuppressants in the bacterial pneumonia group. 
Table 1 Patient characteristics

\begin{tabular}{|c|c|c|c|c|c|}
\hline Characteristics & $\begin{array}{l}\text { Total } \\
n=79\end{array}$ & $\begin{array}{l}\text { Idiopathic } \\
n=34\end{array}$ & $\begin{array}{l}\text { Infection triggered } \\
n=25\end{array}$ & $\begin{array}{l}\text { Non-infection triggered } \\
n=20\end{array}$ & $p$ \\
\hline \multicolumn{6}{|l|}{ Patients' characteristics } \\
\hline Age & 74 (62 to 85$)$ & 75 (64 to 86$)$ & 75 (63 to 82 ) & 72 (62 to 85$)$ & 0.876 \\
\hline Sex & 66 & 29 & 19 & 18 & 0.507 \\
\hline Men (\%) & $83.54 \%$ & $85.29 \%$ & $76 \%$ & $90 \%$ & \\
\hline Smoking history & 61 & 25 & 18 & 18 & 0.271 \\
\hline Yes (\%) & $77.22 \%$ & $73.53 \%$ & $72 \%$ & $90 \%$ & \\
\hline Current smoker & 13 & 5 & 4 & 4 & 0.592 \\
\hline$(\%)$ & $16.46 \%$ & $14.71 \%$ & $16 \%$ & $20 \%$ & \\
\hline \multicolumn{6}{|l|}{ Symptoms } \\
\hline High fever & 43 & 15 & 18 & 10 & 0.094 \\
\hline Yes (\%) & $54.43 \%$ & $44.12 \%$ & $72 \%$ & $50 \%$ & \\
\hline Sore throat & 35 & 8 & 22 & 5 & 0.0001 \\
\hline Yes (\%) & $44.31 \%$ & $23.52 \%$ & $88 \%$ & $25 \%$ & \\
\hline Worsening cough & 50 & 22 & 16 & 12 & 0.808 \\
\hline Yes (\%) & $63.29 \%$ & $64.77 \%$ & $64 \%$ & $60 \%$ & \\
\hline Worsening dyspnea & 75 & 32 & 24 & 19 & 0.926 \\
\hline Yes (\%) & $94.94 \%$ & $94.12 \%$ & $96 \%$ & $95 \%$ & \\
\hline Pre-existing CF-IIPS & & & & & 0.072 \\
\hline IPF & 59 & 25 & 19 & 15 & \\
\hline UCIP & 20 & 9 & 6 & 5 & \\
\hline Prior treatment & & & & & 0.177 \\
\hline No treatment & 47 & 17 & 14 & 16 & \\
\hline Corticosteroid & 9 & 3 & 2 & 4 & \\
\hline Corticosteroid + IS & 6 & 4 & 2 & 0 & \\
\hline Pirfenidone & 9 & 4 & 5 & 0 & \\
\hline Nintedanib & 4 & 3 & 1 & 0 & \\
\hline Corticosteroid + Nintedanib & 4 & 3 & 1 & 0 & \\
\hline HRCT pattern at AE-IIPs onset & & & & & 0.471 \\
\hline Diffuse & 34 & 17 & 7 & 10 & \\
\hline Multifocal & 14 & 7 & 5 & 2 & \\
\hline Peripheral & 31 & 10 & 13 & 8 & \\
\hline \multicolumn{6}{|l|}{ Pulmonary function } \\
\hline $\mathrm{P} / \mathrm{F}$ ratio & $\begin{array}{l}168(83.2 \text { to } 344.1) \\
n=79\end{array}$ & $\begin{array}{l}173.7(54.4 \text { to } 380.9) \\
n=34\end{array}$ & $\begin{array}{l}213.3(46.7 \text { to } 476.7) \\
n=25\end{array}$ & $\begin{array}{l}134.2(55.5 \text { to } 458.6) \\
n=20\end{array}$ & 0.201 \\
\hline FVC (L) & $\begin{array}{l}2.35(0.94 \text { to } 3.01) \\
n=39\end{array}$ & $\begin{array}{l}2.29(1.53 \text { to } 3.07) \\
n=18\end{array}$ & $\begin{array}{l}1.51 \text { (0.78 to } 2.76) \\
n=11\end{array}$ & $\begin{array}{l}2.78 \text { (1.94 to } 4.45) \\
n=10\end{array}$ & 0.002 \\
\hline \%FVC (\%) & $\begin{array}{l}65.55 \text { (39.85 to } 84.02) \\
n=39\end{array}$ & $\begin{array}{l}64.90(47.20 \text { to } 82.66) \\
n=18\end{array}$ & $\begin{array}{l}51.33 \text { (33.34 to 81.62) } \\
n=11\end{array}$ & $\begin{array}{l}73.70(57.00 \text { to } 87.90) \\
n=10\end{array}$ & 0.008 \\
\hline VC (L) & $\begin{array}{l}2.49(1.33 \text { to } 3.05) \\
n=39\end{array}$ & $\begin{array}{l}2.42(1.43 \text { to } 3.15) \\
n=18\end{array}$ & $\begin{array}{l}1.64 \text { (0.83 to } 3.16) \\
n=11\end{array}$ & $\begin{array}{l}2.85 \text { (2.08 to } 4.32) \\
n=10\end{array}$ & 0.002 \\
\hline \%VC (\%) & $\begin{array}{l}70.70(44.60 \text { to } 90.22) \\
n=39\end{array}$ & $\begin{array}{l}67.35(47.00 \text { to } 93.18) \\
n=18\end{array}$ & $\begin{array}{l}52.00(35.16 \text { to } 81.33) \\
n=11\end{array}$ & $\begin{array}{l}81.11(59.91 \text { to } 119.41) \\
n=10\end{array}$ & 0.004 \\
\hline DLco $(\mathrm{mL} / \mathrm{min} / \mathrm{mmHg})$ & $\begin{array}{l}\text { (3.85 to } 11.35) \\
n=30\end{array}$ & $\begin{array}{l}6.44(3.73 \text { to } 12.53) \\
n=16\end{array}$ & $\begin{array}{l}7.74(2.92 \text { to } 11.51) \\
n=7\end{array}$ & $\begin{array}{l}8.04 \text { (4.08 to } 10.09) \\
n=7\end{array}$ & 0.959 \\
\hline \%DLco (\%) & $\begin{array}{l}29.90(16.55 \text { to } 40.02) \\
n=30\end{array}$ & $\begin{array}{l}25.35 \text { (16.05 to } 52.77) \\
n=16\end{array}$ & $\begin{array}{l}33.70(12.40 \text { to } 45.50) \\
n=7\end{array}$ & $\begin{array}{l}32.41 \text { (18.11 to } 44.42) \\
n=7\end{array}$ & 0.951 \\
\hline
\end{tabular}


Table 1 Patient characteristics (Continued)

\begin{tabular}{|c|c|c|c|c|c|}
\hline Characteristics & $\begin{array}{l}\text { Total } \\
n=79\end{array}$ & $\begin{array}{l}\text { Idiopathic } \\
n=34\end{array}$ & $\begin{array}{l}\text { Infection triggered } \\
n=25\end{array}$ & $\begin{array}{l}\text { Non-infection triggered } \\
n=20\end{array}$ & $p$ \\
\hline \multicolumn{6}{|l|}{ Serum markers } \\
\hline $\mathrm{KL}-6(\mathrm{IU} / \mathrm{L})$ & $\begin{array}{l}1117(572 \text { to } 2701) \\
n=79\end{array}$ & $\begin{array}{l}1312(692 \text { to } 2663) \\
n=34\end{array}$ & $\begin{array}{l}1019 \text { (222 to } 3509) \\
n=25\end{array}$ & $\begin{array}{l}1372(659 \text { to } 3528) \\
n=20\end{array}$ & 0.166 \\
\hline SP-D (mg/dL) & $\begin{array}{l}364(45 \text { to } 2711) \\
n=63\end{array}$ & $\begin{array}{l}370(77 \text { to } 2430) \\
n=29\end{array}$ & $\begin{array}{l}320(20 \text { to } 1170) \\
n=20\end{array}$ & $\begin{array}{l}370(133 \text { to } 3180) \\
n=14\end{array}$ & 0.328 \\
\hline LDH (IU/L) & $\begin{array}{l}365(193 \text { to } 539) \\
n=79\end{array}$ & $\begin{array}{l}346(193 \text { to } 546) \\
n=34\end{array}$ & $\begin{array}{l}327(201 \text { to } 765) \\
n=25\end{array}$ & $\begin{array}{l}436(175 \text { to } 652) \\
n=20\end{array}$ & 0.060 \\
\hline $\mathrm{WBC}(/ \mu \mathrm{L})$ & $\begin{array}{l}10,700(6300 \text { to } 15,400) \\
n=79\end{array}$ & $\begin{array}{l}10,400(6200 \text { to } 17,880) \\
n=34\end{array}$ & $\begin{array}{l}10,600(5700 \text { to } 22,900) \\
n=25\end{array}$ & $\begin{array}{l}12,600(2500 \text { to } 22,900) \\
n=20\end{array}$ & 0.918 \\
\hline CRP $(\mathrm{mg} / \mathrm{dL})$ & $\begin{array}{l}8.5(0.7 \text { to } 25) \\
n=79\end{array}$ & $\begin{array}{l}7.3(0.7 \text { to } 22) \\
n=34\end{array}$ & $\begin{array}{l}11.1(0.87 \text { to } 36) \\
n=25\end{array}$ & $\begin{array}{l}7.5(1.3 \text { to } 25.3) \\
n=20\end{array}$ & 0.063 \\
\hline Procalcitonin (ng/mL) & $\begin{array}{l}0.12(0.01 \text { to } 0.74) \\
n=70\end{array}$ & $\begin{array}{l}0.15 \text { (0.01 to } 0.58) \\
n=32\end{array}$ & $\begin{array}{l}0.33(0.07 \text { to } 0.74) \\
n=21\end{array}$ & $\begin{array}{l}0.09(0.01 \text { to } 0.31) \\
n=17\end{array}$ & 0.037 \\
\hline D-dimer (mg/dL) & $\begin{array}{l}3.6(1.38 \text { to } 74.2) \\
n=74\end{array}$ & $\begin{array}{l}3 \text { ( } 1.8 \text { to } 83) \\
n=31\end{array}$ & $\begin{array}{l}2.6(1.3 \text { to } 21.1) \\
n=24\end{array}$ & $\begin{array}{l}6.1(1.2 \text { to } 41.0) \\
n=19\end{array}$ & 0.222 \\
\hline
\end{tabular}

Abbreviations: CF-IIPs Chronic fibrosing idiopathic interstitial pneumonias, IPF Idiopathic pulmonary fibrosis, UCIP Unclassifiable interstitial pneumonia, IS Immunosuppressant, AE-IIPs Acute exacerbation of idiopathic interstitial pneumonias, P/F ratio $\mathrm{PaO}_{2} / \mathrm{FiO}_{2}$ ratio, FVC Forced vital capacity, VC Vital capacity, DLCO Diffusing capacity for carbon monoxide, KL-6 Krebs von den Lungen-6, SP-D Surfactant protein-D, $L D H$ Lactate dehydrogenase, WBC White blood cells, CRP C-related protein

We also analyzed seasonal variations in the development of AE-IIPs. Among patients with infectiontriggered AE-IIPs, 4 developed AE-IIPs in spring, 1 in summer, 5 in autumn, and 14 in winter, representing a significantly higher incidence in winter than in any other season $(p=0.035)$. However, there were no significant differences in the incidence of idiopathic and noninfection-triggered AE-IIPs between any seasons (Fig. 2).

\section{Risk factors associated with AE-IIPs-induced early death}

Tables 4 and 5 present the results of univariate and multivariate analyses of risk factors for early death associated with AE-IIPs. We defined early death as death within 30 days of development of AE-IIPs. In the univariate analysis, $\mathrm{PaO}_{2} / \mathrm{FiO}_{2}$ ratio, HRCT patterns at AE-IIPs onset, treatment prior to AE-IIPs, and clinical AE-IIPs types were significantly associated with early death $\left(\mathrm{PaO}_{2} / \mathrm{FiO}_{2}\right.$ ratio: $\mathrm{OR}=11.511, p=0.0007$; HRCT patterns at AE-IIPs onset: $\mathrm{OR}=16.011, p=0.0003$; and clinical AE-IIPs types: $\mathrm{OR}=13.138, p=0.0009$ ). Multivariate analysis performed using three variables $\left(\mathrm{PaO}_{2} / \mathrm{FiO}_{2}\right.$ ratio, HRCT patterns at AE-IIPs onset, and AE-IIPs types) indicated that HRCT patterns at AE-IIPs onset and clinical AE-IIPs types were significant independent risk factors for early death [clinical AE-IIPs types: OR $=2.375$, $95 \%$ confidence interval $(95 \% \mathrm{CI})=1.173-4.807, \quad p=$ 0.016; and HRCT patterns at AE-IIPs onset: $\mathrm{OR}=2.032$, $95 \% \mathrm{CI}=1.128-3.663, p=0.018]$.

\section{Prognostic differences among AE-IIPs groups}

We evaluated differences in survival among the different types of AE-IIPs and pneumonia superimposed on CF-
IIPs. Although there was no significant difference in MST between idiopathic and all triggered AE-IIPs (idiopathic: 19 days, $95 \% \mathrm{CI}=2.119-35.881$; all triggered: 46 days, $95 \% \mathrm{CI}=15.048-76.952$ ), $\mathrm{MST}$ was significantly longer in patients with pneumonia superimposed on CFIIPs (750 days, $95 \% \mathrm{CI}=248.328-1251.672)$ than that in patients with all triggered or idiopathic AE-IIPs (HR = 25.137, $p=0.0001$, Fig. 3a). Moreover, MST was significantly longer in patients with infection-triggered exacerbations ( 190 days, $95 \% \mathrm{CI}=10.157-369.853$ ) than that in patients with idiopathic or non-infection-triggered AEIIPs (29 days, $95 \% \mathrm{CI}=12.057-43.493, p=0.012$, Fig. 3b).

Finally, we analyzed the mortality rate $15,30,60$, and 90 days after AE-IIPs onset. On all observation days, the mortality rate was significantly lower in infection-triggered $\mathrm{AE}$ IIPs than in idiopathic and non-infection-triggered AE-IIPs. In addition, we also analyzed differences in cause of death among the three groups. Although AE-IIPs itself was the most common cause of death in idiopathic and noninfection-triggered patients, chronic respiratory failure was the most common cause of death in infection-triggered AE-IIPs (Table 6). In addition, there were 5 patients ( 2 with idiopathic, 2 with non-infection-triggered, and one with infection-triggered) who developed recurrent AE-IIPs. There was no significant association between recurrence and clinical AE-IIPs types among three groups.

\section{Discussion}

To our knowledge, the current study is the first to classify AE-IIPs into three groups (idiopathic, infectiontriggered, and non-infection-triggered AE-IIPs) and to evaluate differences in prognosis among the three 
Table 2 The difference of patient characteristics, pulmonary function, and serum markers between AE-IIPs and pneumonia

\begin{tabular}{|c|c|c|c|}
\hline & $\begin{array}{l}\text { AE-IIPs } \\
n=79\end{array}$ & $\begin{array}{l}\text { Pneumonia superimposed on IIPS } \\
n=21\end{array}$ & $p$ \\
\hline \multicolumn{4}{|l|}{ Patient characteristics } \\
\hline Age & 74 (62 to 85$)$ & 75 (66 to 83) & 0.869 \\
\hline Sex & 66 & 18 & 0.807 \\
\hline Men (\%) & $83.54 \%$ & $85.71 \%$ & \\
\hline Smoking history & 61 & 16 & 0.921 \\
\hline Yes (\%) & $77.22 \%$ & $76.19 \%$ & \\
\hline Current smoker & 13 & 3 & 0.357 \\
\hline (\%) & $16.46 \%$ & $14.29 \%$ & \\
\hline \multicolumn{4}{|l|}{ Symptoms } \\
\hline High fever & 43 & 17 & 0.027 \\
\hline Yes (\%) & $54.43 \%$ & $80.91 \%$ & \\
\hline Sore throat & 35 & 19 & 0.008 \\
\hline Yes (\%) & $44.31 \%$ & $90.48 \%$ & \\
\hline Worsening cough & 50 & 15 & 0.661 \\
\hline Yes (\%) & $63.29 \%$ & $71.42 \%$ & \\
\hline Worsening dyspnea & 75 & 18 & 0.321 \\
\hline Yes (\%) & $94.94 \%$ & $85.72 \%$ & \\
\hline Pre-existing CF-IIPS & & & 0.542 \\
\hline IPF & 59 & 17 & \\
\hline UCIP & 20 & 4 & \\
\hline Prior treatment & & & 0.248 \\
\hline No treatment & 47 & 8 & \\
\hline Corticosteroid & 9 & 2 & \\
\hline Corticosteroid + IS & 6 & 2 & \\
\hline Pirfenidone & 9 & 2 & \\
\hline Nintedanib & 4 & 4 & \\
\hline Corticosteroid + Nintedanib & 4 & 3 & \\
\hline \multicolumn{4}{|l|}{ Pulmonary function } \\
\hline $\mathrm{P} / \mathrm{F}$ ratio & $\begin{array}{l}168(83.2 \text { to } 344.1) \\
n=79\end{array}$ & $\begin{array}{l}246(173.7 \text { to } 340.5) \\
n=18\end{array}$ & 0.026 \\
\hline FVC (L) & $\begin{array}{l}2.35(0.94 \text { to } 3.01) \\
n=39\end{array}$ & $\begin{array}{l}2.19 \text { (1.43 to } 3.22) \\
n=17\end{array}$ & 0.807 \\
\hline \%FVC (\%) & $\begin{array}{l}65.55 \text { (39.85 to } 84.02) \\
n=39\end{array}$ & $\begin{array}{l}70.11 \text { (41.98 to } 102.22) \\
n=17\end{array}$ & 0.356 \\
\hline VC (L) & $\begin{array}{l}2.49(1.33 \text { to } 3.05) \\
n=39\end{array}$ & $\begin{array}{l}2.09 \text { (1.24 to } 3.04) \\
n=17\end{array}$ & 0.266 \\
\hline \%VC (\%) & $\begin{array}{l}70.70(44.60 \text { to } 90.22) \\
n=39\end{array}$ & $\begin{array}{l}65.21(40.02 \text { to } 101.61) \\
n=17\end{array}$ & 0.734 \\
\hline DLco $(\mathrm{mL} / \mathrm{min} / \mathrm{mmHg})$ & $\begin{array}{l}7.29(3.85 \text { to } 11.35) \\
n=30\end{array}$ & $\begin{array}{l}5.04 \text { (2.37 to } 8.73) \\
n=17\end{array}$ & 0.006 \\
\hline \%DLco (\%) & $\begin{array}{l}29.90(16.55 \text { to } 40.02) \\
n=30\end{array}$ & $\begin{array}{l}21.00(10.71 \text { to } 40.02) \\
n=17\end{array}$ & 0.014 \\
\hline \multicolumn{4}{|l|}{ Serum markers } \\
\hline KL-6 (IU/L) & $\begin{array}{l}1117(572 \text { to } 2701) \\
n=79\end{array}$ & $\begin{array}{l}517 \text { (296 to 2348) } \\
n=21\end{array}$ & 0.003 \\
\hline $\mathrm{SP}-\mathrm{D}(\mathrm{mg} / \mathrm{dL})$ & $\begin{array}{l}364(45 \text { to } 2711) \\
n=63\end{array}$ & $\begin{array}{l}107(44 \text { to } 303) \\
n=17\end{array}$ & 0.006 \\
\hline
\end{tabular}


Table 2 The difference of patient characteristics, pulmonary function, and serum markers between AE-IIPs and pneumonia (Continued)

\begin{tabular}{|c|c|c|c|}
\hline & $\begin{array}{l}\text { AE-IIPs } \\
n=79\end{array}$ & $\begin{array}{l}\text { Pneumonia superimposed on IIPs } \\
n=21\end{array}$ & $p$ \\
\hline LDH (IU/L) & $\begin{array}{l}365(193 \text { to } 539) \\
n=79\end{array}$ & $\begin{array}{l}231(157 \text { to } 359) \\
n=21\end{array}$ & 0.001 \\
\hline WBC $(/ \mu \mathrm{L})$ & $\begin{array}{l}10,700(6300 \text { to } 15,400) \\
n=79\end{array}$ & $\begin{array}{l}9900(5480 \text { to } 17,880) \\
n=21\end{array}$ & 0.496 \\
\hline CRP (mg/dL) & $\begin{array}{l}8.5(0.7 \text { to } 25) \\
n=79\end{array}$ & $\begin{array}{l}16.4(2.2 \text { to } 35.8) \\
n=21\end{array}$ & 0.011 \\
\hline Procalcitonin (ng/mL) & $\begin{array}{l}0.12(0.01 \text { to } 0.74) \\
n=70\end{array}$ & $\begin{array}{l}1.86(0.46 \text { to } 11.21) \\
n=19\end{array}$ & 0.001 \\
\hline D-dimer (mg/dL) & $\begin{array}{l}3.6(1.38 \text { to } 74.2) \\
n=74\end{array}$ & $\begin{array}{l}2.3(1.2 \text { to } 4.1) \\
n=19\end{array}$ & 0.006 \\
\hline
\end{tabular}

Abbreviations: IIPs Idiopathic interstitial pneumonias, AE-IIPs Acute exacerbation of idiopathic interstitial pneumonias, IPF Idiopathic pulmonary fibrosis, UCIP Unclassifiable interstitial pneumonia, $\mathrm{P} / \mathrm{F}$ ratio $\mathrm{PaO}_{2} / \mathrm{FiO}_{2}$ ratio, $F V C$ Forced vital capacity, VC Vital capacity, DLco Diffusing capacity for carbon monoxide, KL-6 Krebs von den Lungen-6, SP-D Surfactant protein-D, LDH Lactate dehydrogenase, WBC White blood cells, CRP C-related protein

groups. Our main findings are as follows: (i) survival time was significantly longer in patients with infectiontriggered AE-IIPs than in patients with idiopathic or non-infection-triggered AE-IIPs, and moreover, the survival time was significantly longer in patients with pneumonia superimposed on CF-IIPs than in patients with AE-IIPs; (ii) mortality rate was significantly lower in infection-triggered AE-IIPs than in either other type; (iii) the incidence of infection-triggered AE-IIPs in winter was significantly higher than in any other season; (iv) variation in AE-IIPs was not significantly associated with HRCT patterns at AE-IIPs onset and previous treatment; and (v) clinical AE-IIPs types and HRCT patterns at AEIIPs onset were significant independent risk factors for early death induced by AE-IIPs.

Recently, several Japanese publications have reported differences in prognosis between idiopathic and triggered AE-IIPs [21, 22]. However, these differences were not significant. Although there are several different triggers, including infection, drugs, surgery, anesthesia, and bronchoscopy, no previous studies have evaluated whether there are differences in prognosis and patient characteristics among the different triggers. Thus, we focused on the kind of triggers, specifically the presence or

Table 3 The difference of treatment for AE-IIPS

\begin{tabular}{|c|c|c|c|c|c|}
\hline Treatment & $\begin{array}{l}\text { Total } \\
n=79\end{array}$ & $\begin{array}{l}\text { Idiopathic } \\
n=34\end{array}$ & $\begin{array}{l}\text { Infection-triggered } \\
n=25\end{array}$ & $\begin{array}{l}\text { Non-infection-triggered } \\
n=20\end{array}$ & $p$ \\
\hline \multirow[t]{2}{*}{ Admission to intensive care unit } & 55 & 24 & 17 & 14 & \multirow[t]{2}{*}{0.796} \\
\hline & $69.62 \%$ & $70.59 \%$ & $68 \%$ & $70 \%$ & \\
\hline \multirow[t]{2}{*}{ Only intensive care unit admission } & 13 & 7 & 2 & 4 & \multirow[t]{2}{*}{0.325} \\
\hline & $16.46 \%$ & $20.59 \%$ & $8 \%$ & $20 \%$ & \\
\hline \multirow{2}{*}{$\begin{array}{l}\text { Intravenous } \\
\text { high-dose steroids }\end{array}$} & 79 & 34 & 25 & 20 & \multirow[t]{2}{*}{1.000} \\
\hline & $100 \%$ & $100 \%$ & $100 \%$ & $100 \%$ & \\
\hline \multirow[t]{2}{*}{ Immunosuppressant } & 34 & 17 & 9 & 8 & \multirow[t]{2}{*}{0.413} \\
\hline & $43.03 \%$ & $50 \%$ & $36 \%$ & $40 \%$ & \\
\hline \multirow[t]{2}{*}{ Antibiotics } & 79 & 34 & 25 & 20 & \multirow[t]{2}{*}{1.000} \\
\hline & $100 \%$ & $100 \%$ & $100 \%$ & $100 \%$ & \\
\hline \multirow[t]{2}{*}{ Invasive ventilation } & 7 & 3 & 1 & 3 & \multirow[t]{2}{*}{0.386} \\
\hline & $8.86 \%$ & $8.82 \%$ & $4 \%$ & $15 \%$ & \\
\hline \multirow[t]{2}{*}{ NPPV } & 14 & 6 & 4 & 4 & \multirow[t]{2}{*}{0.894} \\
\hline & $17.72 \%$ & $17.65 \%$ & $16 \%$ & $20 \%$ & \\
\hline \multirow[t]{2}{*}{ High-flow therapy } & 51 & 25 & 12 & 14 & \multirow[t]{2}{*}{0.103} \\
\hline & $64.56 \%$ & $73.53 \%$ & $48 \%$ & $70 \%$ & \\
\hline
\end{tabular}




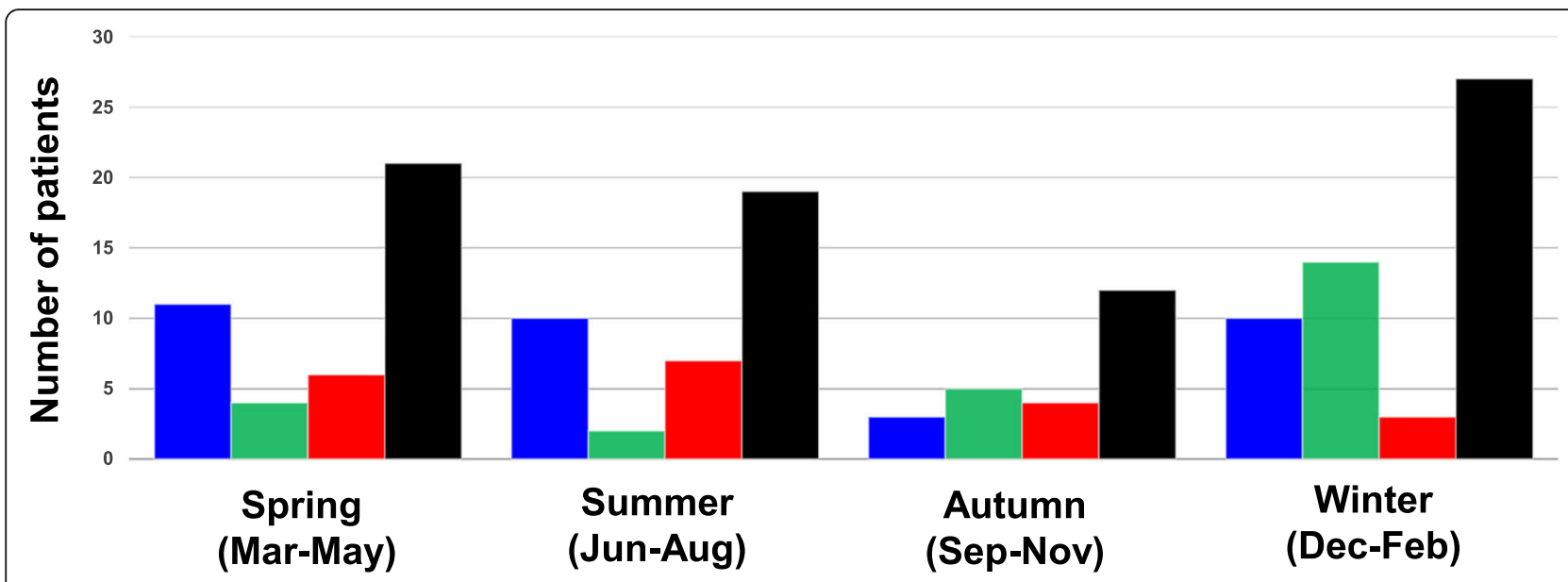

Fig. 2 Differences in seasonal incidence of AE-IIPs among the three groups. Blue, green, red, and black bars indicate the number of patients with idiopathic, infection-triggered, non-infection-triggered, and total AE-IIPS, respectively

absence of infections, and evaluated differences in prognosis among idiopathic, infection-triggered, and noninfection-triggered AE-IIPs.

In terms of prognosis, MST for infection-triggered AE-IIPs was the longest, followed by idiopathic, and then non-infection-triggered AE-IIPs. Moreover, there was a significant difference in the most common cause of death between infection-triggered and non-infectiontriggered/idiopathic AE-IIPs. All patients received antibiotics. Therefore, control of infection may be associated with attenuation of infection-related inflammation and injury, thereby improving the survival time in patients with infection-triggered AE-IIPs. In contrast, we suggest that for any triggers other than infection it is extremely difficult to inhibit or attenuate the lung injury induced by drugs, biopsy, surgery, or anesthesia because these triggers cause chemical or physical injury. Survival in patients with idiopathic AE-IIPs was intermediate between patients with infection-triggered and non-infectiontriggered AE-IIPs.

Moreover, it may be also difficult to accurately classify idiopathic and infection-triggered AE-IIPs. In this study, we classified patients with symptoms related to upper respiratory tract inflammation, as having infectiontriggered AE-IIPs. Corticosteroid treatment is known to interfere with the development of a fever. When a patient receives corticosteroids, they may not develop fever and other symptom associated with influenza virus infection. This patient would be classified as having the idiopathic type. Thus, treatment of baseline CF-IIPs may increase the selection bias, and idiopathic AE-IIPs may include unknown triggers that are both infection and non-infection related. Although the frequency of high fever was significantly higher in bacterial pneumonia superimposed on CF-IIPs patients than that in AE-IIPs, there were several patients who received corticosteroids in all categories and almost all of these patients did not have high fever in all clinical AE-IIPs types. Therefore, the data may be indeterminate for evaluating whether a high fever is associated with AE-IIPs in patients who received corticosteroids.

The evaluation of procalcitonin levels may be useful for the distinguishing among clinical AE-IIPs types, and between AE-IIPs and bacterial pneumonia. In this study, the levels of procalcitonin was significantly higher in patients with infection-triggered than in patients with other clinical AE-IIPs. Then, the levels of procalcitonin was significantly higher in patients with bacterial pneumonia superimposed on CF-IIPs than in patients with AE-IIPs, especially in infection-triggered AE-IIPs. Therefore, evaluation of procalcitonin levels may be reasonable to distinguish bacterial pneumonia and AE-IIPs and to classify among clinical AE-IIPs types. However, the patients could easily succumb to other bacterial after viral infection compared with healthy individuals; thus, only evaluating procalcitonin and/or CRP levels may not be useful for distinguishing among the clinical AE-IIPs types, and between AE-IIPs and bacterial pneumonia superimposed on CF-IIPs.

Further, whereas there was significant difference in survival time among three groups, the three survival curves almost overlapped immediately after the development of AE-IIPs. Therefore, we were unable to evaluate the prognosis and severity during from the early phase to the development of AE-IIPs, for distinguishing the clinical AE-IIPs types. In contrast, no patients with bacterial pneumonia superimposed on CF-IIPs were admitted to only the intensive care unit (ICU). In addition, the survival curve evidently differed between AE-IIPs and bacterial pneumonia superimposed on CF-IIPs from the early phase of AE-IIPs. Thus, we believe that the difference in ICU admission, which reflects on the severity, 
Table 4 The difference of patient characteristics, pulmonary function, and serum markers between survivors and non-survivors

\begin{tabular}{|c|c|c|c|c|c|}
\hline \multirow[t]{2}{*}{ Variables } & \multirow{2}{*}{$\begin{array}{l}\text { Overall } \\
n=79\end{array}$} & \multirow{2}{*}{$\begin{array}{l}\text { survivor } \\
n=42\end{array}$} & \multirow{2}{*}{$\begin{array}{l}\text { Non-survivor } \\
n=37\end{array}$} & \multirow[t]{2}{*}{ OR } & \multirow[t]{2}{*}{$p$} \\
\hline & & & & & \\
\hline \multicolumn{6}{|l|}{ Patient background } \\
\hline Age & 74 (62 to 86 ) & 75 (64 to 86$)$ & 74 (62 to 85$)$ & 1.113 & 0.374 \\
\hline Sex & 66 & 32 & 34 & 3.333 & 0.126 \\
\hline Man (\%) & $83.54 \%$ & $76.19 \%$ & $91.89 \%$ & & \\
\hline Smoking history & 61 & 31 & 30 & 1.428 & 0.597 \\
\hline Yes (\%) & $77.22 \%$ & $73.81 \%$ & $81.08 \%$ & & \\
\hline Current smoker & 13 & 7 & 6 & 1.128 & 0.973 \\
\hline Yes (\%) & $16.46 \%$ & $16.67 \%$ & $14.29 \%$ & & \\
\hline Time to diagnosis of IIPs & $33.25 \pm 38.39$ & $31.20 \pm 35.24$ & $37.76 \pm 42.36$ & 2.176 & 0.124 \\
\hline \multicolumn{6}{|l|}{ Symptoms } \\
\hline High fever & 43 & 23 & 20 & 1.012 & 0.949 \\
\hline Yes (\%) & $54.43 \%$ & $54.76 \%$ & $54.05 \%$ & & \\
\hline Sore throat & 35 & 22 & 13 & 3.841 & 0.132 \\
\hline Yes (\%) & $44.13 \%$ & $52.38 \%$ & $35.14 \%$ & & \\
\hline Worsening cough & 50 & 27 & 23 & 1.011 & 0.969 \\
\hline Yes (\%) & $63.29 \%$ & $64.28 \%$ & $62.16 \%$ & & \\
\hline Worsening dyspnea & 75 & 39 & 36 & 1.618 & 0.701 \\
\hline Yes (\%) & $94.94 \%$ & $92.85 \%$ & $97.29 \%$ & & \\
\hline Pre-existing CF-IIPS & & & & 0.409 & 0.815 \\
\hline IPF & 59 & 33 & 26 & & \\
\hline UCIP & 20 & 9 & 11 & & \\
\hline Prior treatment & & & & 2.793 & 0.593 \\
\hline No treatment & 47 & 28 & 19 & & \\
\hline Corticosteroid & 9 & 4 & 5 & & \\
\hline Corticosteroid + IS & 6 & 2 & 4 & & \\
\hline Pirfenidone & 9 & 5 & 4 & & \\
\hline Nintedanib & 4 & 2 & 2 & & \\
\hline Corticosteroid + Nintedanib & 4 & 1 & 3 & & \\
\hline Clinical AE-IIPs types & & & & 13.138 & 0.0009 \\
\hline Idiopathic & 34 & 12 & 22 & & \\
\hline Infection-triggered & 25 & 20 & 5 & & \\
\hline Non-infection-triggered & 20 & 10 & 10 & & \\
\hline HRCT patterns at AE-IIPs onset & & & & 16.011 & 0.0003 \\
\hline Diffuse & 34 & 9 & 25 & & \\
\hline Multifocal & 14 & 12 & 2 & & \\
\hline Peripheral & 31 & 21 & 10 & & \\
\hline \multicolumn{6}{|l|}{ Pulmonary function } \\
\hline $\mathrm{P} / \mathrm{F}$ ratio & $\begin{array}{l}168(83.2 \text { to } 344.1) \\
n=79\end{array}$ & $\begin{array}{l}246 \text { (103 to } 362) \\
n=42\end{array}$ & $\begin{array}{l}132(67 \text { to } 339) \\
n=37\end{array}$ & 11.510 & 0.0007 \\
\hline VC (\%) & $\begin{array}{l}2.49 \text { (1.33 to } 3.05) \\
n=39\end{array}$ & $\begin{array}{l}2.43(0.95 \text { to } 3.45) \\
n=23\end{array}$ & $\begin{array}{l}2.58(1.87 \text { to } 3.45) \\
n=16\end{array}$ & 2.329 & 0.127 \\
\hline VC (L) & $\begin{array}{l}70.70(44.60 \text { to } 90.22) \\
n=39\end{array}$ & $\begin{array}{l}69.55 \text { (38.50 to } 93.55) \\
n=23\end{array}$ & $\begin{array}{l}71.21(48.63 \text { to } 99.74) \\
n=16\end{array}$ & 0.655 & 0.418 \\
\hline
\end{tabular}


Table 4 The difference of patient characteristics, pulmonary function, and serum markers between survivors and non-survivors (Continued)

\begin{tabular}{|c|c|c|c|c|c|}
\hline \multirow[t]{2}{*}{ Variables } & \multirow{2}{*}{$\begin{array}{l}\text { Overall } \\
n=79\end{array}$} & \multirow{2}{*}{$\begin{array}{l}\text { survivor } \\
n=42\end{array}$} & \multirow{2}{*}{$\begin{array}{l}\text { Non-survivor } \\
n=37\end{array}$} & \multirow[t]{2}{*}{ OR } & \multirow[t]{2}{*}{$p$} \\
\hline & & & & & \\
\hline FVC (\%) & $\begin{array}{l}2.35(0.94 \text { to } 3.01) \\
n=39\end{array}$ & $\begin{array}{l}2.35(0.89 \text { to } 3.45) \\
n=23\end{array}$ & $\begin{array}{l}2.38(1.84 \text { to } 3.47) \\
n=16\end{array}$ & 2.212 & 0.136 \\
\hline FVC (L) & $\begin{array}{l}65.55 \text { (39.85 to } 84.02) \\
n=39\end{array}$ & $\begin{array}{l}65.33 \text { (35.58 to } 86.82) \\
n=23\end{array}$ & $\begin{array}{l}67.51(50.20 \text { to } 86.00) \\
n=16\end{array}$ & 1.084 & 0.297 \\
\hline $\mathrm{DLco}(\mathrm{mL} / \mathrm{min} / \mathrm{mmHg})$ & $\begin{array}{l}7.29 \text { (3.85 to } 11.35) \\
n=30\end{array}$ & $\begin{array}{l}7.63(4.33 \text { to } 11.76) \\
n=16\end{array}$ & $\begin{array}{l}6.79(3.68 \text { to } 11.45) \\
n=14\end{array}$ & 0.080 & 0.776 \\
\hline DLco (\%) & $\begin{array}{l}29.90(16.55 \text { to } 40.02) \\
n=30\end{array}$ & $\begin{array}{l}31.5(17.68 \text { to } 51.08) \\
n=16\end{array}$ & $\begin{array}{l}26.35(15.75 \text { to } 44.70) \\
n=14\end{array}$ & 0.356 & 0.551 \\
\hline \multicolumn{6}{|l|}{ Serum markers } \\
\hline $\mathrm{KL}-6$ (IU/L) & $\begin{array}{l}1117(572 \text { to } 2701) \\
n=79\end{array}$ & $\begin{array}{l}1086(569 \text { to } 2882) \\
n=42\end{array}$ & $\begin{array}{l}1166(583 \text { to } 2585) \\
n=37\end{array}$ & 28.571 & 0.938 \\
\hline $\mathrm{SP}-\mathrm{D}(\mathrm{mg} / \mathrm{dL})$ & $\begin{array}{l}364(45 \text { to } 2711) \\
n=63\end{array}$ & $\begin{array}{l}362(148 \text { to } 987) \\
n=36\end{array}$ & $\begin{array}{l}370(76 \text { to } 1382) \\
n=27\end{array}$ & 1.612 & 0.424 \\
\hline LDH (IU/L) & $\begin{array}{l}365 \text { (193 to } 539) \\
n=79\end{array}$ & $\begin{array}{l}350(249 \text { to } 539) \\
n=42\end{array}$ & $\begin{array}{l}368(228 \text { to } 540) \\
n=37\end{array}$ & 5.586 & 0.671 \\
\hline WBC $(/ \mu \mathrm{L})$ & $\begin{array}{l}10,700(6300 \text { to } 15,400) \\
n=79\end{array}$ & $\begin{array}{l}10,690(5960 \text { to } 15,900) \\
n=42\end{array}$ & $\begin{array}{l}11,300(8600 \text { to } 14,600) \\
n=37\end{array}$ & 4.037 & 0.620 \\
\hline CRP (mg/dL) & $\begin{array}{l}8.5(0.7 \text { to } 25) \\
n=79\end{array}$ & $\begin{array}{l}7.5(1.98 \text { to } 24.65) \\
n=42\end{array}$ & $\begin{array}{l}8.8(1.86 \text { to } 21.76) \\
n=37\end{array}$ & 37.037 & 0.987 \\
\hline Procalcitonin (ng/mL) & $\begin{array}{l}0.12(0.01 \text { to } 0.74) \\
n=70\end{array}$ & $\begin{array}{l}0.12(0.01 \text { to } 0.74) \\
n=38\end{array}$ & $\begin{array}{l}0.10(0.01 \text { to } 0.68) \\
n=32\end{array}$ & 1.021 & 0.878 \\
\hline D-dimer (mg/dL) & $\begin{array}{l}3.6(1.38 \text { to } 74.2) \\
n=74\end{array}$ & $\begin{array}{l}3.1(1.27 \text { to } 17.18) \\
n=41\end{array}$ & $\begin{array}{l}4.9(1.88 \text { to } 33.32) \\
n=33\end{array}$ & 2.002 & 0.157 \\
\hline
\end{tabular}

Abbreviations: OR Odds ratio, CF-IIPs Chronic fibrosing idiopathic interstitial pneumonias, IPF Idiopathic pulmonary fibrosis, UCIP Unclassifiable interstitial pneumonia, $P / F$ ratio $\mathrm{PaO}_{2} / \mathrm{FiO}_{2}$ ratio, FVC Forced vital capacity, VC Vital capacity, DLco Diffusing capacity for carbon monoxide, KL-6 Krebs von den Lungen-6, SP-D Surfactant protein-D, LDH Lactate dehydrogenase, WBC White blood cells, CRP C-related protein

may be associated with the difference in clinical course and pathogenesis between AE-IIPs and bacterial pneumonia superimposed on CF-IIPs.

The major causes of death in IPF have been shown to be AE-IIPs, development of lung cancer, and chronic respiratory failure, based on previous reports [23, 24]. Respiratory failure is defined as a decrease in $\mathrm{PaO}_{2}$ and a $>45$ Torr in Japan. Following the development of chronic respiratory failure in CF-IIPs patients, the patient's quality of life decreases, and the risk of comorbidities associated with CF-IIPs increases. These patients die due to respiratory failure. In this study, there were no patients who died of lung cancer after the development of AE-IIPs. The difference in the cause of death

Table 5 Multivariate analysis of risk factors associated with AEIIPs-induced death within 30 days

\begin{tabular}{llll}
\hline Variable & OR & $95 \% \mathrm{Cl}$ & $p$ \\
\hline P/F ratio & 0.989 & $0.983-0.996$ & 0.0001 \\
Clinical AE-IIPs types & 2.375 & $1.173-4.807$ & 0.016 \\
HRCT patterns at AE-IIPs onset & 2.032 & $1.128-3.663$ & 0.018 \\
\hline
\end{tabular}

Abbreviations: OR Odds ratio, $95 \% \mathrm{Cl} 95 \%$ confidence interval, $\mathrm{P} / \mathrm{F}$ ratio $\mathrm{PaO}_{2} /$ $\mathrm{FiO}_{2}$ ratio, $A E-I I P s$ Acute exacerbation associated with idiopathic interstitial pneumonias, HRCT High resolution computed tomography between this study and the recent study [24] in total IPF was considered to be the difference in prognosis between the patients with and without AE-IIPs. It was reported that the survival time in patients with AE-IIPs was significantly shorter than that in patients without AE-IIPs. The difference in prognosis may associate with differences in the cause of death [20,24].

The incidence of AE-IIPs in winter was only significantly higher in infection-triggered AE-IIPs compared with other types of AE-IIPs. In the INPULSIS trial, a phase 3 clinical trial of nintedanib for IPF, the incidence of AE-IIPs was also higher in winter than in other seasons [25]. In this study, AE-IIPs was not divided into idiopathic and triggered types. Consistent with this, another publication has reported that the incidence of AEIIPs in winter is significantly higher than that in the other seasons [26]. However, although Teramachi et al. reported a higher AE-IIPs incidence in idiopathic patients in winter than in other seasons, there was no significant seasonal difference in patients with triggered AE-IIPs [21]. In general, AE-IIPs more commonly develop in winter than in other seasons because viral respiratory infections and other winter-specific factors may be associated with the development of AE-IIPs. 


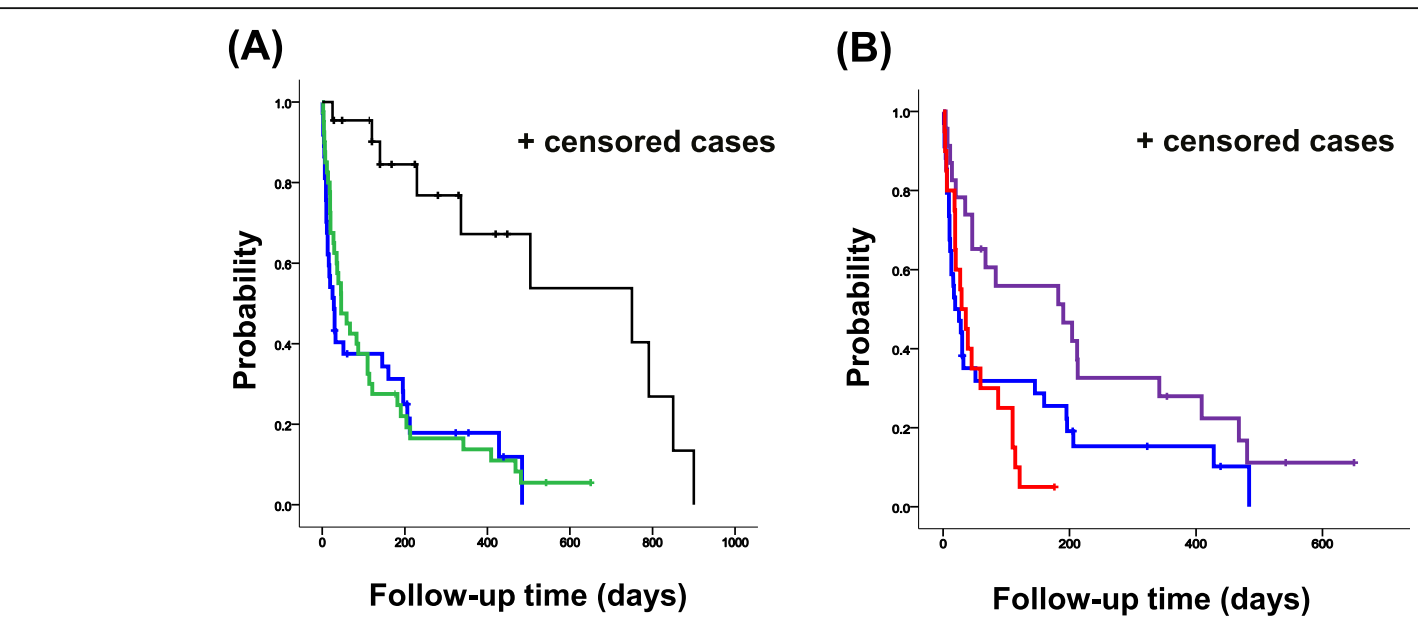

Fig. 3 Survival curves. a Survival time from development of AE-IIPs or pneumonia among idiopathic, all triggered (infection-triggered and noninfection-triggered) AE-IIPS, and pneumonia superimposed on CF-IIPs. Blue, green, and black lines indicate the number of patients and survival for idiopathic, all triggered AE-IIPs, and pneumonia superimposed on CF-IIPs, respectively. p-value was calculated using the log-rank test. $\mathbf{b}$ Difference in survival time from AE-IIPs onset. Blue, red, and purple lines indicate the number of patients and survival for idiopathic, non-infection-triggered, infection-triggered AE-IIPS, respectively. $p$-value was calculated using the log-rank test

This conclusion is supported by the results of the INPULSIS trial, as well as our current results.

This study is subject to several limitations. First, this was a small retrospective study. Although there was a moderate number of patients with CF-IIPs at our hospital, the incidence of AE-IIPs was approximately 10$20 \%$ per year $[4,24]$. Therefore, it is difficult to recruit a large number of patients who have developed AE-IIPs. Second, almost patients were diagnosed and classified into each CF-IIPs based on HRCT findings, serological findings, and medical examination by an interview, but not on histological findings. Therefore, the patients' backgrounds were heterogeneous, and survival may have resulted from selection bias. Then, although 3 patients showed a NSIP pattern (GGO and/or reticular shadow on the bronchovascular bundles) on the HRCT, these patients were diagnosed with UCIP due to presence of both UIP and NSIP patterns or other mixed pathological

Table 6 Mortality and cause of death

\begin{tabular}{|c|c|c|c|c|c|}
\hline & $\begin{array}{l}\text { Total } \\
n=79\end{array}$ & $\begin{array}{l}\text { Idiopathic } \\
n=34\end{array}$ & $\begin{array}{l}\text { Infection-triggered } \\
n=25\end{array}$ & $\begin{array}{l}\text { Non-infection-triggered } \\
n=20\end{array}$ & $p$ \\
\hline \multicolumn{6}{|l|}{ Mortality } \\
\hline 14 days & $\begin{array}{l}22 \\
27.84 \%\end{array}$ & $\begin{array}{l}14 \\
41.18 \%\end{array}$ & $\begin{array}{l}4 \\
16 \%\end{array}$ & $\begin{array}{l}4 \\
20 \%\end{array}$ & 0.049 \\
\hline 28 days & $\begin{array}{l}37 \\
46.83 \%\end{array}$ & $\begin{array}{l}22 \\
64.71 \%\end{array}$ & $\begin{array}{l}5 \\
20 \%\end{array}$ & $\begin{array}{l}10 \\
50 \%\end{array}$ & 0.029 \\
\hline 56 days & $\begin{array}{l}41 \\
51.89 \%\end{array}$ & $\begin{array}{l}21 \\
61.76 \%\end{array}$ & $\begin{array}{l}8 \\
32 \%\end{array}$ & $\begin{array}{l}12 \\
60 \%\end{array}$ & 0.025 \\
\hline 90 days & $\begin{array}{l}50 \\
63.29 \%\end{array}$ & $\begin{array}{l}24 \\
70.59 \%\end{array}$ & $\begin{array}{l}11 \\
44 \%\end{array}$ & $\begin{array}{l}15 \\
75 \%\end{array}$ & 0.022 \\
\hline The number of already death patients & $\begin{array}{l}70 \\
88.61 \%\end{array}$ & $\begin{array}{l}29 \\
85.29 \%\end{array}$ & $\begin{array}{l}22 \\
88 \%\end{array}$ & $\begin{array}{l}19 \\
95 \%\end{array}$ & \\
\hline \multicolumn{6}{|l|}{ Cause of death } \\
\hline AE-IIPS & $\begin{array}{l}40 \\
57.97 \%\end{array}$ & $\begin{array}{l}25 \\
86.21 \%\end{array}$ & $\begin{array}{l}5 \\
23.81 \%\end{array}$ & $\begin{array}{l}10 \\
52.63 \%\end{array}$ & 0.0003 \\
\hline Bacterial pneumonia & $\begin{array}{l}6 \\
8.67 \%\end{array}$ & $\begin{array}{l}1 \\
3.45 \%\end{array}$ & $\begin{array}{l}4 \\
19.05 \%\end{array}$ & $\begin{array}{l}1 \\
5.26 \%\end{array}$ & \\
\hline Chronic respiratory failure & $\begin{array}{l}18 \\
26.09 \%\end{array}$ & $\begin{array}{l}3 \\
10.34 \%\end{array}$ & $\begin{array}{l}9 \\
42.86 \%\end{array}$ & $\begin{array}{l}6 \\
31.57 \%\end{array}$ & \\
\hline Others & $\begin{array}{l}6 \\
8.67 \%\end{array}$ & $\begin{array}{l}0 \\
0 \%\end{array}$ & $\begin{array}{l}4 \\
19.05 \%\end{array}$ & $\begin{array}{l}2 \\
10.52 \%\end{array}$ & \\
\hline
\end{tabular}


features. We considered it to be a coincidence that there were no patients diagnosed with NSIP by small group bias. Moreover, there were no significant differences in baseline IIPs types among the clinical AE-IIPs types and between AE-IIPs and bacterial pneumonia superimposed on CF-IIPs Thus, it may not be important to classify IIPs in detail to distinguish among the clinical AE-IIPs types and baseline IIPs types in order to predict the prognosis of AE-IIPs in our study. Third, it was strictly difficult to distinguish between infection-triggered AE-IIPs and development of bacterial pneumonia in patients with CF-IIPs. Although MST was significantly longer in bacterial pneumonia than in infection-triggered AE-IIPs, patients who only developed pneumonia may be accidentally confused with infection-triggered AE-IIPs. Fourth, in our study, we collected the data on pulmonary function within 6 months of the development of AEIIPs. Since the pulmonary function results were over 6 months old, this was not appropriate for evaluating the association between the pulmonary function and AEIIPs development. Therefore, we evaluated pulmonary function in only 39 patients. Evaluation of pulmonary function only using data from half of the total patients may result in a lower accuracy.

\section{Conclusion}

Our findings suggest that patients with infection-triggered AE-IIPs have a better prognosis than do patients with other types of AE-IIPs.

\section{Abbreviations \\ 95\% Cl: 95\% confidence interval; AE: Acute exacerbation; AE-IIPs: Acute exacerbation of interstitial pneumonia; AE-IPF: Acute exacerbation of idiopathic pulmonary fibrosis; ATS: American Thoracic Society; CF- IIPS: Chronic fibrosing idiopathic interstitial pneumonias; CHF: Congestive heart failure; CRP: C-related protein; DLco: Diffusing capacity for carbon monoxide; FVC: Forced vital capacity; GGO: Ground-glass opacities; HR: Hazard ratio; HRCT: High resolution computed tomography; ICU: Intensive care unit; IIPS: Idiopathic interstitial pneumonias; IPF: Idiopathic pulmonary fibrosis; KL-6: Krebs von den Lungen-6; LDH: Lactate dehydrogenase; MST: Median survival time; NSIP: Non-specific interstitial pneumonia; OR: Odds ratio; P/F ratio: PaO2/FiO2 ratio; SP-D: Surfactant protein-D; UCIP: Unclassifiable interstitial pneumonia; VC: Vital capacity}

\section{Acknowledgements}

We would like to thank Editage for English language editing.

\begin{abstract}
Authors' contributions
MK had full access to all of the data in this study and takes responsibility for the integrity of the data and the accuracy of this data analysis and wrote the manuscript. MK and SS designed the study. TY, SK, YA, and KM contributed to acquisition of clinical data. TY, YO, and $\mathrm{HI}$ analyzed the data. MK, SS, and RK evaluated chest HRCT findings. MK, SS, and KT provided final approval of the version to be published. All authors read and approved the final manuscript.
\end{abstract}

\section{Funding}

No funding.

Availability of data and materials Not applicable.

\section{Ethics approval and consent to participate}

The study protocol was approved by Juntendo University's ethics committee (number 19-015). The ethics committee waived the requirement for informed consent because of the retrospective nature of the research.

Consent for publication

Not applicable.

\section{Competing interests}

The authors declare that they have no competing interests.

Received: 7 August 2019 Accepted: 25 November 2019

Published online: 18 December 2019

References

1. Kondoh Y, Taniguchi H, Kawabata Y, Yokoi T, Suzuki K, Takagi K. Acute exacerbation in idiopathic pulmonary fibrosis analysis of clinical and pathologic findings in three cases. Chest. 1993;103:1808-12.

2. Collard HR, Ryerson CJ, Corte TJ, Jenkins G, Kondoh Y, Lederer DJ, Lee JS, Maher TM, Wells AU, Antoniou KM, et al. Acute exacerbation of idiopathic pulmonary fibrosis an international working group report. Am J Respir Crit Care Med. 2016;194:265-75.

3. Song JW, Koh Y, Kim DS. Acute exacerbation of idiopathic pulmonary fibrosis: incidence, risk factors and outcome. Eur Respir J. 2011;37:356-63.

4. Collard HR, Moore BB, Flaherty KR, Brown KK, Kaner RJ, King TE Jr, Lasky JA, Loyd JE, Noth I, Olman MA, et al. Acute exacerbations of idiopathic pulmonary fibrosis. Am J Respir Crit Care Med. 2007;176:636-43.

5. Toyoda Y, Hanibuchi M, Kishi J, Kawano H, Morizumi S, Sato S, Kondo M, Takikura T, Tezuka T, Goto H, et al. Clinical features and outcome of acute exacerbation of interstitial pneumonia associated with connective tissue disease. J Med Investig. 2016;63:294-9.

6. Enomoto N, Oyama Y, Enomoto Y, Yasui H, Karayama M, Kono M, Hozumi H, Suzuki Y, Furuhashi K, Fujisawa T, et al. Differences in clinical features of acute exacerbation between connective tissue disease-associated interstitial pneumonia and idiopathic pulmonary fibrosis. Chron Respir Dis. 2018;16:1-8.

7. Hariri LP, Mino-kenudson M, Shea B, Fraire AE, Matsubara O, Mark EJ. Distinct histopathology of acute onset or abrupt exacerbation of hypersensitivity pneumonitis. Hum Pathol. 2012:43:660-8.

8. Usui Y, Kaga A, Sakai F, Shiono A, Komiyama K, Hagiwara K, Kanazawa M. A cohort study of mortality predictors in patients with acute exacerbation of chronic fibrosing interstitial pneumonia. BMJ Open. 2013;3:e002971.

9. Miyamoto A, Sharma A, Nishino M, Kenudson MM, Matsubara O. Expanded acceptance of acute exacerbation of nonspecific interstitial pneumonia, including 7 additional cases with detailed clinical pathologic correlation. Pathol Int. 2018;68:401-8.

10. Suzuki A, Kimura T, Kataoka K, Matsuda T, Yokoyama T. Acute exacerbation of idiopathic pulmonary fi brosis triggered by Aspergillus empyema. Respir Med Case Reports. 2019;23:103-6.

11. Ushiki A, Yamazaki Y, Hama M. Viral infections in patients with an acute exacerbation of idiopathic interstitial pneumonia. Respir Investig. 2019:52:65-70.

12. Qiu M, Chen Y, Ye Q. Risk factors for acute exacerbation of idiopathic pulmonary fibrosis : a systematic review and meta-analysis. Clin Respir J. 2018;12:1084-92.

13. Bando M, Ohno S, Oshikawa K, Talahashi M, Okamoto H, Sugiyama Y. Infection of TTvirus in patients with idiopathic pulmonary fibrosis. Respir Med. 2001;95:935-42.

14. Kondoh Y, Taniguchi H, Kitaichi M, Yokoi T, Johkoh T, Oishi T, Kimura T, Nishiyama O, Kato K, du Bois RM. Acute exacerbation of interstitial pneumonia following surgical lung biopsy. Respir Med. 2006;100:1753-9.

15. Sakamoto S, Homma S, Mun M, Fujii T, Kurosaki A, Yoshimura K. Acute exacerbation of idiopathic interstitial pneumonia following lung surgery in 3 of 68 consecutive patients : a retrospective study. Intern Med. 2011;50:77-85.

16. Suzuki H, Sekine $Y$, Yoshida S, Suzuki M, Shibuya K, Yonemori Y, Hiroshima K, Nakatani Y, Mizuno S, Takiguchi Y, et al. Risk of acute exacerbation of interstitial pneumonia after pulmonary resection for lung Cancer in patients with idiopathic pulmonary fibrosis based on preoperative high-resolution. Surg Today. 2011:41:914-21.

17. Wootton SC, Kim DS, Kondoh Y, Chen E, Lee JS, Song JW, Huh JW, Taniguchi $\mathrm{H}$, Chiu C, Boushey $\mathrm{H}$, et al. Viral infection in acute exacerbation of idiopathic pulmonary fibrosis. Am J Respir Crit Care Med. 2011;183:1698-702. 
18. Travis WD, Costabel U, Hansell DM, King TE Jr, Lynch DA, Nicholson AG, Ryerson CJ, Ryu JH, Selman M, Wells AU, et al. An official American Thoracic Society/European Respiratory Society statement: update of the international multidisciplinary classification of the idiopathic interstitial pneumonias. Am J Respir Crit Care Med. 2013;188:733-48.

19. Nakamura Y, Sugino K, Kitani M, Hebisawa A, Tochigi N, Homma S. Clinicoradio-pathological characteristics of unclassifiable idiopathic interstitial pneumonias. Respir Investig. 2018:56:40-7.

20. Kakugawa T, Sakamoto N, Sato S, Yura H, Harada T, Nakashima S, Hara A, Oda K, Ishimoto H, Yatera K, et al. Risk factors for an acute exacerbation of idiopathic pulmonary fibrosis. Respir Res. 2016;17:79.

21. Teramachi R, Kondoh Y, Kataoka K, Taniguchi H. Outcomes with newly proposed classi fi cation of acute respiratory deterioration in idiopathic pulmonary fibrosis. Respir Med. 2018;143:147-52.

22. Yamazoe $\mathrm{M}$, Tomioka $\mathrm{H}$. Acute exacerbation of idiopathic pulmonary fibrosis : a 10-year single-Centre retrospective study. BMJ Open. 2018;5: e000342.

23. Lederer DJ, Martinez FJ. Idiopathic pulmonary fibrosis. N Engl J Med. 2018; 378:1811-23.

24. Natsuizaka M, Chiba H, Kuronuma K, Otsuka M, Kudo K, Mori M, Bando M, Sugiyama Y, Takahashi H. Epidemiologic survey of Japanese patients with idiopathic pulmonary fibrosis and investigation of ethnic differences. Am J Respir Crit Care Med. 2014;190:773-9.

25. Collard HR, Richeldi L, Kim DS, Taniguchi H, Tschoepe I, Luisetti M, Roman J, Tino G, Schlenker-Herceg R, et al. Acute exacerbations in the INPULSIS trials of nintedanib in idiopathic pulmonary fibrosis. Eur Respir J. 2017:49:1-7.

26. Collard HR, Yow E, Richeldi L, Anstrom KJ, Glazer C. Suspected acute exacerbation of idiopathic pulmonary fibrosis as an outcome measure in clinical trials. Respir Res. 2013;14:73.

\section{Publisher's Note}

Springer Nature remains neutral with regard to jurisdictional claims in published maps and institutional affiliations.

Ready to submit your research? Choose BMC and benefit from:

- fast, convenient online submission

- thorough peer review by experienced researchers in your field

- rapid publication on acceptance

- support for research data, including large and complex data types

- gold Open Access which fosters wider collaboration and increased citations

- maximum visibility for your research: over $100 \mathrm{M}$ website views per year

At $\mathrm{BMC}$, research is always in progress.

Learn more biomedcentral.com/submissions 